\title{
ON THE SKULL MORPHOLOGY OF RACCOON DOG (NYCTEREUTES PROCYONOIDES) AND RED FOX (VULPES VULPES)
}

\author{
Eugenijus JURGELĖNAS ${ }^{1}$, Linas DAUGNORA ${ }^{1}$, Eglè MONASTYRECKIENË르, Linas BALČIAUSKAS ${ }^{3}$
}

${ }^{1}$ The Department of Anatomy and Physiology of the Lithuanian Veterinary Academy, Tilžès 18, LT-47181 Kaunas, Lithuania. E-mail:jurgelin@lva.lt

${ }^{2}$ The Radiology Clinic of Kaunas University of Medicine, Eivenių 2, LT-50161 Kaunas, Lithuania. E-mail: monast@dr.com ${ }^{3}$ Institute of Ecology of Vilnius University, Akademijos 2, LT-08412 Vilnius, Lithuania. E-mail: linasbal@ekoi.lt

\begin{abstract}
The aim of this work was to perform analysis of the skull morphology of red fox and raccoon dog and to examine their frontal sinuses (sinus frontalis) with the help of the methods of comparative anatomy and computed tomography. A total of 71 skulls of adult animals were used, 38 of red fox (22 male and 16 female) and 33 of raccoon dogs (21 male and 12 female). The most distinct morphological features were found in cranium bones, especially in frontal and occipital bones. The mandible was found to have four distinctive morphological features concentrated in the mandibular ramus (ramus mandibulae). The frontal sinuses in raccoon dog, unlike in red fox, occupy the entire surface of the zygomatic processes and are divided into small cavities by well-developed osseous partitions that are very thin in red fox. Computed tomography performed for the sagittal skull area revealed two prominent osseous partitions in the median part of the frontal sinuses in raccoon dogs and one partition in red fox. The maximum length, width and height of the frontal sinus cavity are larger in red fox than in raccoon dog $(p<0.001)$.
\end{abstract}

Key words: raccoon dog, red fox, skull, morphology, computed tomography (CT)

\section{INTRODUCTION}

Out of six known raccoon dog (Nyctereutes procyonoides Gray) subspecies, N. p. ussuriensis migrated to the European part of Russia during the first half of the last century and later spread into other regions of Europe (Kauhala et al. 1998). Nowadays, the species is widely distributed across Europe (Mitchel-Jones et al. 1999). Raccoon dog reached Lithuania from Belarus in 1948, where it was introduced in 1936, and subsequently the second wave of migration followed from Latvia, where the species was introduced in 1948 (Logminas et al. 1982; Prūsaite et al. 1988). Raccoon dog is widely distributed and common in Lithuania (Balčiauskas et al. 1999). Fox (Vulpes vulpes) and raccoon dog are poorly studied in Lithuania and the records concerned are very outdated (Prūsaite 1960a, b). Lately, only the diet of both species has been the focus of scientific attention (Baltrūnaitė 2005, 2006).

Anatomical characteristics of different animal species and interspecific differences are determined by the method of morphological analysis. This method is not fully reliable to study peculiarities of the internal skull structure or interspecific differences, because it involves a vast amount of research material. Analysis of the internal skull structure is greatly facilitated by computed tomography (Alpak 2003). This method helps to make a more precise assessment of normal and affected tissues, which would be impossible to achieve by an ordinary radiological examination (Fike et al. 1984). Recently, computed tomography has been also applied in osteological studies.

The aim of our study was to perform analysis of the skull morphology of red fox and raccoon dog and to examine their frontal sinuses (sinus frontalis) using the methods of comparative anatomy and computed tomography. Results of analysis of the cranial morphology of these two species could be useful in the studies of fossil bone material and in veterinary forensic investigation. Usually, only skull fragments constitute the material of zooarchaeological and veterinary expertise. The results of this study would contribute to interspecies identification of the discussed species.

\section{MATERIAL AND METHODS}

The skulls of foxes and raccoon dogs hunted in different regions of Lithuania from 2003 to 2005 were studied ( 5 samples were obtained from Jurbarkas district, 
20 from Kaunas, 10 - Alytus, 8 - Tauragè, 9 - Kèdainiai, 7 - Utena, 1 - Telšiai and 11 from Zarasai districts). Only intact and bullet-hole-free skulls of adult animals with closed cranial sutures were used in the study. Heads were boiled, soft tissues were removed and skulls were dried. A total of 71 skulls were examined.

Overall, 45 skulls, 25 of red fox (13 male and 12 female) and 20 of raccoon dog (12 male and 8 female), were analysed by the method of comparative anatomy to determine macroscopically visible skull characters. Pictures were taken with a digital Hewlett Packard Photosmart M305 camera.

The frontal sinuses of 20 more skulls, of which 10 belonged to raccoon dog ( 7 male and 3 female) and 10 to red fox (7 male and 3 female), were analysed employing the computed tomography method. Computed tomography was performed using 6-slice 'Somatom Emotion 6' (Siemens) and 16-slice 'Light speed' (General Electric) tomographs. Slice thickness was $1 \mathrm{~mm}$, increment $0.5 \mathrm{~mm}$, table feed $2.5 \mathrm{~mm}$, kernel $\mathrm{AH} 70$ and $\mathrm{AH}$ 40. Two- and three-dimensional reconstructions were made. Measurements of the frontal sinus cavities were performed, the length was measured between the most distal oral and aboral sinus walls, the height was measured at the sinus apex, whereas the width between the lateral margins of both sinuses located in the zygomatic processes of the frontal bones. For macroscopic analysis of sinuses, the frontal bones of six more skulls, of which three were of red fox ( 2 males and 1 female) and three of raccoon dogs ( 2 male and 1 female) were abraded: at a surface level (frontal sinuses were opened after filing down the osseous plate), mid-level (to the median zygomatic processes of the frontal bones) and deep level (the processes of the zygomatic bones were filed down). Cranial description was based on Latin anatomical terms (ICVGAN 1994; Daugnora et al. 1998).

A standard statistical approach (mean and standard error, and Student $t$-test for the comparison of means) was used. The comparison of shares of skulls with specific character in both species was done using $\chi^{2}$ method $(2 \times 2$ tables $)$. Calculations were done with Statistica for Windows ver. 6.0 (StatSoft 2004).

\section{Results}

1. Macroscopic cranial analysis. The external sagittal crest (crista sagitalis externa) is more pronounced in raccoon dog and markedly extends into the frontal bone, but at the margin of the interparietal bone (os interparietale) this process is well developed in both red fox and raccoon dog. The external occipital crest (crista occipitalis externa) in raccoon dog is more prominent than in red fox and divides the squamous part of the occipital bone (squama occipitalis) into two equal parts. The condylar canal (canalis condylaris) in red fox is double, whereas that in raccoon dog single. Eight out of 25 red fox skulls (accounting for $32 \%$ ) possessed an open condylar canal in the ventral condylar fossa (fossa condylaris ventralis) (Fig. 1, B), the same was true for 3 out of 20 raccoon dog skulls $(15 \%)$, but the difference was not significant $\left(\chi^{2}=1.74, p=0.18\right)$. The paracondylar processes (processus paracondylaris) in red fox extend ventrolaterally, whereas those in raccoon dog ventrally. The basilar part of the occipital bone in red fox (pars basilaris) is wider than in raccoon dog (Fig. 1, A). Both species have the foramen magnum (foramen magnum) of an oval shape, whereas the ventral margin of the foramen is $\mathrm{V}$-shaped in red fox and more U-shaped in raccoon dog (Fig. 1, C). The ethmoidal foramen (foramen ethmoidale) is double in red fox and single in raccoon dog. The zygomatic processes of the frontal bones (processus zygomaticus ossis frontalis) in raccoon dog run in ventrolateral direction, whereas those in red fox in lateral. The frontal processes of the zygomatic bones (processus frontalis ossis zygomatici) in raccoon dog are much better pronounced than in red fox. The orbital sur-

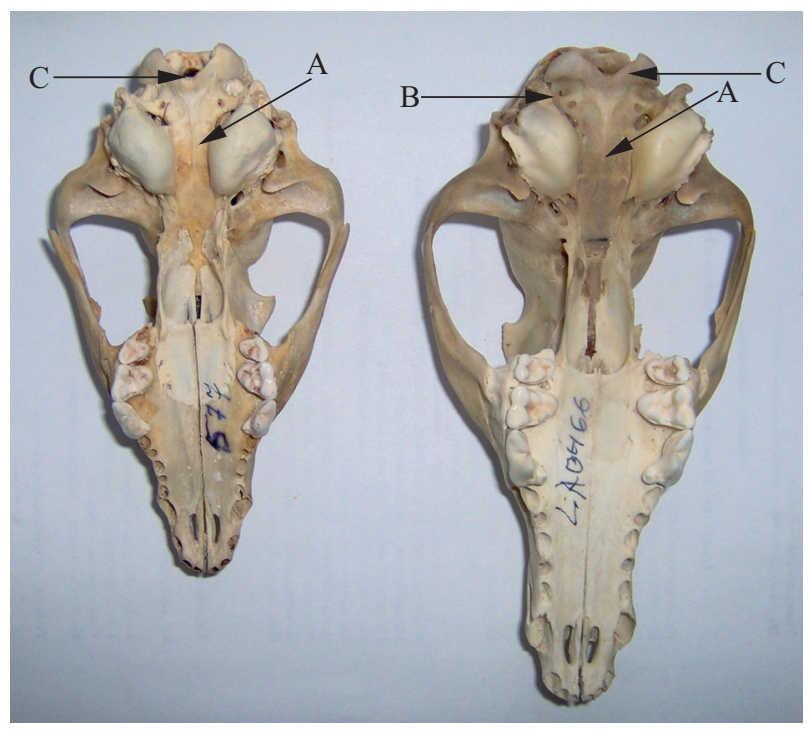

Figure 1. The ventral surface of raccoon dog (left) and red fox (right) skulls. A - the basilar part of the occipital body is wider in red fox, $\mathrm{B}$ - the open condylar canal in the ventral condylar fossa, $\mathrm{C}$ - the $\mathrm{V}$-shaped ventral margin of the foramen magnum in red fox and U-shaped in raccoon dog. 
face (facies orbitalis) of the lacrimal bone is ventrally wider in raccoon dog than in red fox. Insicura sphenoidalis between the wings of the vomer (ala vomeris) is wider in raccoon dog than in red fox. The end of the angular process of the mandible (processus angularis) in raccoon dog is blunt, whereas that in red fox is pointed (Fig. 2, B). The ventral margin of the mandible ramus (ramus mandibulae) in raccoon dog has a deep indentation, which is not marked in red fox (Fig. 2, A). The masseteric fossa (fossa masseterica) in red fox occupies nearly the entire surface of the ramus, whereas that in raccoon dog runs to the cervical line of the molar teeth (Fig. 2, C). The aboral margin of the mandible ramus located between the angular and articular processes in raccoon dog is archshaped, whereas in red fox it is hook-shaped.

\section{Morphological analysis of frontal sinuses. Ex-} amination of the frontal sinus area in raccoon dog showed well-defined osseous partitions (Fig. 3), which are very thin in red fox (Fig. 4).

The frontal sinuses in raccoon dogs nearly fully overlap with the zygomatic processes, whereas in red fox no overlap was observed. Examination of the frontal bone area bellow the level of zygomatic processes revealed no clear morphological distinctions between the two species.

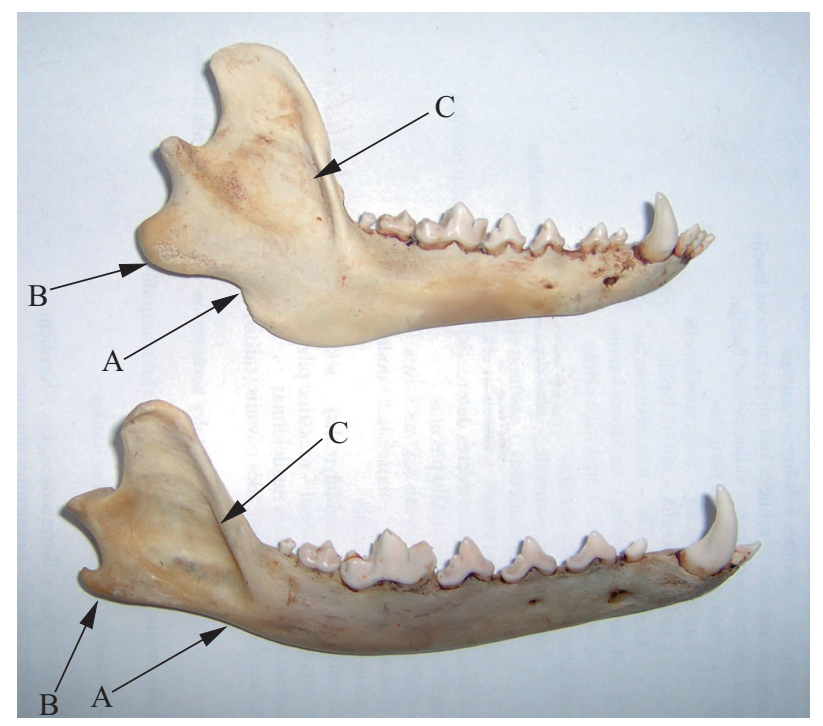

Figure 2. The lateral surface of the right mandible of raccoon dog (top) and of red fox (bottom), A - the ventral indentation of the mandible ramus, $\mathrm{B}$ - the angular process is blunt in raccoon dog and pointed in red fox, $\mathrm{C}-$ the masseteric fossa.
The serial skull sagittal sections were made with the help of computed tomography. Raccoon dog has two osseous partitions in the median part of the frontal sinuses (Fig. 5). Red fox has only one apparent partition (Fig. 6).

3. Osteometric analysis of frontal sinuses. The maximum lengths of the frontal sinuses found for red fox and raccoon dog were $40.3 \pm 3.93 \mathrm{~mm}$ and $31.52 \pm$ $1.98 \mathrm{~mm}$; widths $-23.92 \pm 1.42 \mathrm{~mm}$ and $18.51 \pm$ $1.83 \mathrm{~mm}$; heights $-10.44 \pm 1.33 \mathrm{~mm}$ and $8.40 \pm$ $0.94 \mathrm{~mm}$, respectively. All measurements in red fox were found to be larger than in raccoon $\operatorname{dog}(p<0.001)$.

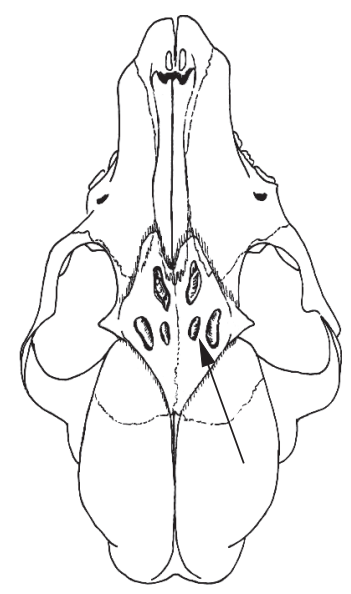

Figure 3. The frontal sinuses of raccoon dog. The arrow indicates the osseous partitions.

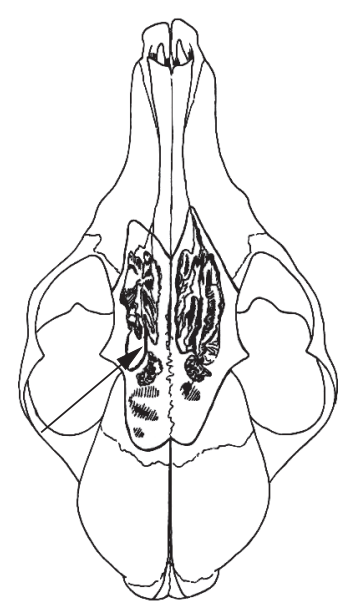

Figure 4. The frontal sinuses of red fox. The arrow indicates the osseous partitions. 


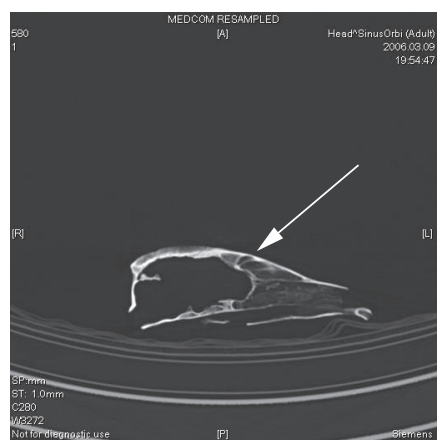

Figure 5. The sagittal section of the raccoon dog skull (computed tomography). The arrow indicates the osseous partitions.

\section{Discussion}

Though studies on the skeletal morphology of wild predators are carried out on a rather large scale, we failed to find data of comparative approach to the skull morphology of red fox and raccoon dog. Studies on skull osteometry of red fox and raccoon dog were carried out in Lithuania (Jurgelènas \& Daugnora 2005), but comparison was not made.

Craniological studies on different raccoon dog subspecies were carried out in Finland (Kauhala et al. 1998). Japanese scientists compared the skulls of badgers (Meles meles) and raccoon dogs belonging to different families (Hidaka et al. 1998). Comparative craniological analysis was done for several predator species: dog, cat, badger, marten (Martes foina) and otter (Lutra lutra) (Karan et al. 2006). Studies of skull morphology of red fox (Sjøvold 1977) and variations in skull morphology of farmed arctic fox (Alopex lagopus L.) (Welling et al. 2001) were also conducted. Morphological variations, arrangement and pathological deformities of the dental structure of red fox were studied in Poland (Szuma 2000, 2002). Variations in the tooth structure of predator representatives were also analysed (Meiri et al. 2005). Israeli scientists also studied the impact of diet on the size of badger and red fox skulls (Yom-Tov et al. 2003).

Our comparative analysis revealed a well-pronounced external sagittal crest in raccoon dog. This anatomical peculiarity in raccoon dog was also reported by Hidaka et al. (1998). Our data also confirm a double condylar canal in red fox, reported by Sjøvold (1977). An open condylar canal was reported in red fox (Sjøvold 1977), but our results indicate that this canal was found in only $32 \%$ of red fox and $15 \%$ of raccoon dog skull specimens.

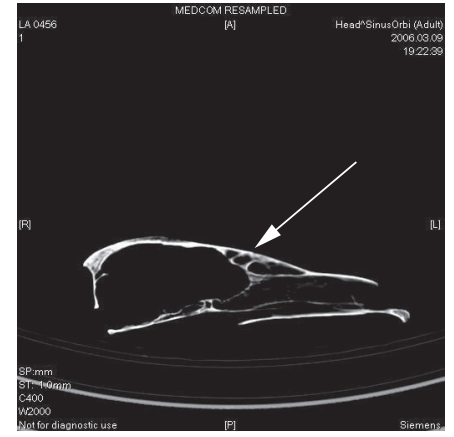

Figure 6. The sagittal section of the red fox skull (computed tomography). The arrow indicates the osseous partitions.

We found that the paracondylar processes in raccoon dog are directed ventrally, whereas in red fox ventrolaterally. The ventral direction of paracondylar processes is also observed in dogs, cats, badgers and martens (Karan et al. 2006). We also found that both species investigated possess an oval-shaped foramen magnum. The same shape for raccoon dogs was reported by Hidaka et al. (1998), whereas for dogs, cats, badgers and martens by Karan et al. (2006).

Well-articulated zygomatic processes of the frontal bones are typical of dogs, badges and martens, whereas in cats they extend to the frontal processes of the zygomatic bones (Karan et al. 2006). These processes were also well developed in the species involved in our study, but their direction was different, ventrolateral in raccoon dog and lateral in red fox. A deep indentation in the ventral margin of the mandible ramus in raccoon dog was reported by Hidaka et al. (1998). The same indentation was also found in the skulls examined in our study. The accessory mental foramens in red fox were reported by Sjøvold (1977), but they were not confirmed by our data.

In classical veterinary literature, the frontal sinuses in domestic dog have two parts: lateral and median. The median part of the frontal sinus has no definite location; therefore various structural variations are possible depending on the shape of the skull (Nickel et al. 1987). The lateral part of the sinus in long-muzzled breeds is relatively large and that in short-muzzled dogs is small, whereas the median part is strongly reduced or absent (Evans \& Christensen 1979).

The skulls of red fox and raccoon dog differ in their length; those of red fox are longer as compared to the skulls the latter species (Jurgelènas \& Daugnora 2005). Macroscopic examination of the frontal sinuses after the osseous plate was removed revealed osseous par- 
titions that divide frontal sinuses into separate small cavities. These osseous partitions are very well pronounced in raccoon dog. A similar structure of frontal sinuses is characteristic of Japanese wolf and Akita dogs (Hideki et al. 1997).

After the abrasion of the frontal bone area to the median part of the zygomatic processes, we found that the frontal sinuses in raccoon dog nearly fully overlap with zygomatic processes. In contrast, the zygomatic processes in red fox are not interrupted by the frontal sinuses, which was confirmed by macroscopic and computed tomography examination. The overlap of frontal sinuses with zygomatic bones was reported in Beagle dogs by Fike et al. (1984), as well as in Akita dogs and Japanese wolves (Canis hodophilax) by Hideki et al. (1997).

Our results on differences in cranial morphology of red fox and raccoon dog can be used in the studies of fossil bone material, veterinary forensic investigations and in zoological research. In the first case, computed tomography is recommended as a method that does not require to destroy osseous material.

\section{ACKNOWLedGements}

The authors appreciate the help from Dr M. Šarkūnas, J. Pumputyte, R. Bružinskaitè and G. Vaickute, who prepared and provided study material.

\section{REFERENCES}

Alpak, H. 2003. Morphometry of the mandible of German Shepherd dog (Alsatian) puppies using computed tomographic analysis. Israel Journal of Veterinary Medicine 58 (1): 15-17.

Balčiauskas, L., Trakimas, G., Juškaitis, R., Ulevičius, A. and Balčiauskienè, L. 1999. Atlas of Lithuanian mammals, amphibians and reptiles. Second edition (revised). Vilnius: Akstis. [Balčiauskas, L., Trakimas, G., Juškaitis, R., Ulevičius, A., Balčiauskienė, L. 1999. Lietuvos žinduoliu, varliagyviu ir ropliu atlasas. Antras papildytas leidimas. Vilnius: Akstis.]

Baltrūnaite, L. 2005. Seasonal diet diversity of raccoon $\operatorname{dog}$ (Nyctereutes procyonoides Gray.) in different landscapes, Lithuania. Acta biologica universitatis Daugavpiliensis 5 (1): 75-83.

Baltrūnaite, L. 2006. Diet and winter habitat use of the red fox, pine marten and raccoon dog in Dzūkija National Park, Lithuania. Acta Zoologica Lituanica 16 (1): 46-53.

Daugnora, L., Padaiga, A., Vitkus, A., Paunksnienè, M., Daugèla, A., Liutkevičius, G., Babrauskienè, V. and
Alionienė I. 1998. The terms of veterinary anatomy, histology and embryology. Kaunas: Candela. [Daugnora, L., Padaiga, A., Vitkus, A., Paunksnienè, M., Daugèla, A., Liutkevičius, G., Babrauskienè, V., Alionienė I. 1998. Veterinarinés anatomijos, histologijos ir embriologijos terminai. Kaunas: Candela.]

Evans, H. E. and Christensen, G. C. 1979. Miller's Anatomy of the Dog. Philadelphia, PA: W. B. Saunders Company.

Fike, J. R., LeCouteur, R. A. and Cann, E. F. 1984. Anatomy of the canine orbital region. Multiplanar Imaging by CT. Veterinary Radiology 25 (1): 32-36.

Hidaka, S., Matsumoto, M., Hiji, H., Ohsako, S. and Nishinakagawa, H. 1998. Morphology and Morphometry of Skulls of Raccoon Dogs, Nyctereutes procyonoides and Badgers, Meles meles. Journal of Veterinary and Medical Science 60 (2): 161-167.

Hideki, E., Obara, I., Yoshida, T., Kurohmaru, M., Hayashi, Y. and Suzuki, N. 1997. Osteometrical and CT Examination of the Japanese Wolf Skull. Journal of Veterinary and Medical Science 59 (7): 531-538.

International Committee on Veterinary Gross Anatomical nomenclature [ICVGAN] 1994. Nomina Anatomica Veterinaria. $4^{\text {th }}$ edition. Gent: World Association of Veterinary Anatomist.

Jurgelènas, E. and Daugnora, L. 2005. Osteometric study of red fox and raccoon dog skulls. Veterinary and zootechnics 32 (54): 11-15. [Jurgelènas, E., Daugnora, L. 2005. Rudosios lapès ir usūrinio šuns kaukolių osteometrinis tyrimas. Veterinarija ir zootechnika 32 (54): 11-15.

Karan, M., Timurkaan, S., Özdemir, D. and Ünsaldi, E. 2006. Comparative Macroanatomical Study of the Neurocranium in some Carnivora. Anatomy of Histological Embryology 35: 53-56.

Kauhala, K., Viranta, S., Kishimoto, M., Helle, E. and Obara, I. 1998. Skull and tooth morphology of Finnish and Japanese raccoon dogs. Annales Zoologici Fennici 35: 1-16.

Logminas, V., Prūsaite, J. and Virbickas, J. 1982. Guide to Lithuanian vertebrates. Vilnius: Mokslas. [Logminas, V., Prūsaitè, J., Virbickas, J. 1982. Vadovas Lietuvos stuburiniams pažinti. Vilnius: Mokslas.]

Meiri, S., Dayan, T. and Simberloff, D. 2005. Variability and correlations in carnivore crania and dentition. Functional Ecology 19: 337-343.

Mitchell-Jones, A. J., Amori, G., Bogdanowicz, W., Kryštufek, B., Reijnders, P. J. H., Spitzenberger, F., Stubbe, M., Thissen, J. B. M., Vohralik, V. and Zima, J. 1999. The Atlas of European Mammals. London: Academic Press.

Nickel, R., Schummer, A. and Seiferle, E. 1987. The Anatomy of the Domestic Animals. Vol. 1. Berlin: Verlag Paul Parey. 
Prūsaite, J. 1960a. The distribution and diet of the raccoon dog (Nyctereutes procyonoides Gray) in Lithuania. Proceedings of the Lithuanian Academy of Sciences. Series C 2 (22): 125-140. [Prūsaitè, J. 1960a. Usūrinio šuns (Nyctereutes procyonoides Gray) plitimas ir mityba Lietuvoje. Lietuvos TSR MA darbai, Ser. C 2 (22): 125-140.]

Prūsaite, J. 1960b. The biology of Lithuanian red fox. Proceedings of the Lithuanian Academy of Sciences. Series C 3 (23): 191-210. [Prūsaitè, J. 1960b. Lietuvos ruduju lapių biologija. Lietuvos TSR MA darbai, Ser. C 3 (23): 191-210.]

Prūsaitè, J. (comp.) 1988. Fauna of Lithuania. Mammals. Vilnius: Mokslas. [Prūsaitė, J. (sud.) 1988. Lietuvos fauna. Žinduoliai. Vilnius: Mokslas.]

Sjøvold, T. 1977. Non-metrical divergence between skeletal population. Ossa 4: 55-110.

StatSoft, Inc. 2004. Statistica (data analysis software system), version 6. www.statsoft.com.

Szuma, E. 2000. Variation and correlation patterns in the dentition of the red fox from Poland. Annales Zoologici Fennici 37: 113-127.

Szuma, E. 2002. Dental polymorphism in a population of the red fox (Vulpes vulpes) from Poland. Journal of Zoology, London 256: 243-253.

Welling, J., Harri, M., Rekila, T., Rouvinen-Watt, K. and Braastad, B. O. 2001. Variation between ranch blue fox populations in cranial form. Journal of Animal Breeding and Genetics 118 (1): 37-45.

Yom-Tov, Y., Yom-Tov, S. and Baagøe, H. 2003. Increase of skull size in the red fox (Vulpes vulpes) and Eurasian badger (Meles meles) in Denmark during the twentieth century: an effect of improved diet? Evolution Ecology Research 5: 1037-1048.

\section{USŪRINIO ŠUNS (NYCTEREUTES PROCYONOIDES) IR LAPĖS (VULPES VULPES) KAUKOLIU MORFOLOGINIS TYRIMAS}

\author{
E. Jurgelènas, L. Daugnora, \\ E. Monastyreckienè, L. Balčiauskas
}

\section{SANTRAUKA}

Šio darbo tikslas - atlikti rudujų lapių ir usūrinių šunų kaukolių morfologinę analizę, ištirti kaktikaulio ančius (sinus frontalis) palyginamosios anatomijos ir kompiuterinès tomografijos metodais. Viso tyrimui panaudota 71 suaugusių žvėrelių kaukolių kaukolè, rudujų lapių 38 (patinų 22, patelių 16), usūrinių šunų 33 (patinų 21, patelių 12). Atlikus morfologinę analizę ryškiausi ypatumai nustatyti kiaušo kauluose, ypač pakauškaulio ir kaktikaulio kauluose. Apatinis žandikaulis turi keturis ryškius morfologinius ypatumus, esančius apatinio žandikaulio šakoje (ramus mandibulae). Usūriniams šunims kaktikaulio ančiai užima beveik visą skruostinių ataugų plotą, rudosioms lapėms kaktikaulio ančiai į šias ataugas neịsiterpia. Usūriniams šunims kaktikaulio ančius į nedideles ertmes suskirsto gerai išreikštos kaulinès pertvaros, rudujų lapių šios pertvaros labai plonos. Sagitalinèje kaukolès plokštumoje padarytos kompiuterinès tomogramos usūriniams šunims parodè dvi, rudosioms lapėms vieną ryškią pertvarą kaktikaulio ančių vidurinejje dalyje. Išmatavus kaktikaulio ančių ertmės didžiausią ilgi, aukšti ir plotị, rudujų lapių visi šie matmenys yra didesni nei usūrinių šunų $(p<0,001)$.

Received: 21 December 2006 Accepted: 17 January 2007 